\section{Ikke bare svulsten}

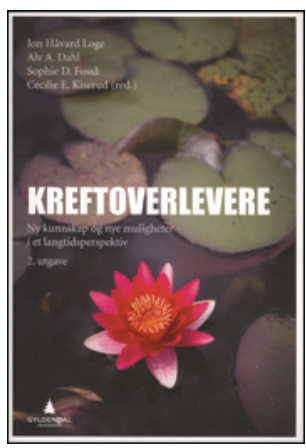

Jon Håvard Loge, Alv A. Dahl,

Sophie D. Fosså et al, red.

Kreftoverlevere

Ny kunnskap og nye muligheter i et langtidsperspektiv. 2. utg. 259 s, tab, ill. Oslo:

Gyldendal Akademisk, 2013. Pris NOK 395

ISBN 978-82-05-45235-0
Kreft har alltid vært en illevarslende diagnose, men moderne medisin kan tilby alle kreftpasienter bedre lindring enn tidligere. De fleste får også økt levetid, og en stadig større andel blir helbredet. Det har gjort at man nå kan snakke om «vedvarende overlevere» etter kreft, gjerne definert som mennesker som er i live mer enn ett år etter diagnose. Lever man fem år etter diagnosen, er man «langtidsoverlever». Men kreftoverlevere lever ofte med seneffekter av sykdom og behandling, og dette er tema for denne oversiktlige og opplysende boken. Den første utgaven kom i 2009, og denne andre utgaven innebærer en ganske omfattende revidering.

Boken inneholder 17 kapitler og starter med en grei oversikt over kreftoverlevelse i tall. Det fortsetter med en god omtale av kreftbehandling og medisinske problemer hos kreftoverlevere. Hjernen, hjertet, hormonsystemet, fordøyelseskanalen og andre organer kan påvirkes av kreftbehandling for kortere eller lengre tid, og risikoen for ny kreftsykdom er økt. De spesielle problemene som er knyttet til kreftbehandling hos barn og ungdom, er gitt god plass. Kapitlet om kjønnshormoner og fruktbarhet følges prisverdig av et opplysende kapittel om seksualitet. Tretthet har fått et eget kapittel og leder over til psykiske problemer, som diskuteres ganske inngående. I de tre kapitlene om livskvalitet, pårørendes situasjon og problemer med dagliglivets aktiviteter, der Ellen Karine Grov er førsteforfatter, er en innledende pasientkasuistikk variert for å illustrere temaet. Dette fungerer bra pedagogisk. Det er balanserte kapitler om fysisk aktivitet og ernæring, og et tillegg om røykeslutt. I de to oversiktlige kapitlene om rehabilitering og sosiale støtteordninger er retten til samtykkebasert individuell plan et viktig poeng. Kreftforeningens mange gode tilbud presenteres i et eget kapittel.

Det er et kort, oppsummerende kapittel som også berører den betydningen våre helseregistre, våre befolkningsundersøkelser og kreftoverleveres villighet til å delta i kliniske etterundersøkelser har for våre forskningsmuligheter. De fleste, men ikke alle kapitlene har oppdaterte referanser. Referanser er et problem i moderne lærebøker fordi selv de mest oppdaterte raskt blir mindre aktuelle enn det man kan finne på internett. Av den grunn inneholder 2013utgaven av læreboken Allmennmedisin ikke referanser. Til gjengjeld viser teksten til aktuelle studier, og det samme gjøres på en god måte i Kreftoverlevere.
Som allmennlege har jeg kikket litt ekstra etter hvilken rolle vår yrkesgruppe tillegges i forhold til kreftoverlevere. I det ellers utmerkede behandlingskapitlet er det nevnt mange yrkesgrupper som har en rolle i tiden etter kreftbehandling, men ikke allmennleger. Utenom byene foregår imidlertid mye viktig kreftbehandling og oppfølging i regi av allmennleger, og det skrives stadig flere publikasjoner om emnet av fagfolk knyttet til forskningsnettverket The Cancer and Primary Care Research International Network (Ca-PRI). En norsk studie har antydet at mange kreftpasienter i den første tiden etter avsluttet behandling ikke har noe stort behov for oppfølging fra fastlegen - kanskje har mange et behov for å distansere seg litt fra sykdomsrollen og få være litt i fred for helsevesenet. Men dersom sykdommen blir mer aktiv, eller seneffektene mer følbare, kan fastlegen bli viktig. Det har vært foreslått at sykehuslegen ved avsluttet kreftbehandling bør spørre om hvilken rolle pasienten ønsker at fastlegen skal ha. Når det gjelder pasienter med aktiv sykdom, vil de fleste fastleger være positive til et tverrfaglig møte med pasienten til stede, slik man praktiserer hos Nav. Sykehusene må ta Fugellis kritikk av manglende legekontinuitet alvorlig og ikke laste dette over på fastlegen alene. Det er likevel ingen tvil om at fastlegen i mange tilfeller vil kunne representere et fastere holdepunkt for pasientens tvil og tanker. Denne moderne diskusjonen reflekteres i liten grad i boken.

Det er ikke helt klart hvem boken skal være opplysende for. Både helsepersonell, kreftpasienter og pårørende nevnes som målgruppe, og boken bærer litt preg av at de forskjellige kapitlene har forskjellige krav til forkunnskaper. Iblant kan den bli litt ordrik for fagpersoner, men med 19 bidragsytere har teksten likevel et ganske enhetlig preg. Alt i alt vil både allmennleger, hjemmesykepleiere og legfolk som lever med eller nær kreft, få et bredt og moderne bilde av hvilke problemer en kreftoverlever og dennes nærmeste kan bli nødt til å hanskes med.

\section{Knut Arne Holtedahl}

Professor, Institutt for samfunnsmedisin

Universitetet i Troms 